\title{
"Seeing All Things as Nothing" : Meister Eckhart and the Incarnation
}

\author{
Nicholas Collura \\ Boston College
}

\section{Introduction}

The Dominican Meister Eckhart (1260-1327) is infamous for the difficulty of his thought, though many of his popular apologists are quick to soft-pedal this concern, calling him a "practical man" who "played down the importance of visions and ecstasy" 1 and "understood how ordinary people lived"; 2 who "catches the interest of most people who read him"; 3 and whose vocation was to preach rather than "to create a theological system." "There is some truth to these generous claims. At the same time, Eckhart himself admitted openly to his audiences that he often had no idea how to communicate at their level, ${ }^{5}$ and would make the occasional reference to "coarseminded" readers too dense to grasp his point. ${ }^{6}$ This is not to say that his genius and esoteric spirituality inclined him towards, or derived from, pretentiousness. In the middle of one sermon, he proclaims, "All sorrow and all joy come from love," and then explains, as an aside, "On the way, when I had to come here, I was thinking that I did not want to come here because then I would become wet with tears of love." 7

Yet this tender tearfulness is not mere sentimentality; a true awe at being overwhelmed him. His two major biblical commentaries are on the prologues of Genesis and John, stories of origin, and creation. In each of these commentaries, he returns to Averroes's insistence on understanding the "what-it-is of things." 8 The idea of the "ground" of being obsesses him." Although he is not prone to mystical visions, he seems constantly on the verge of a limit experience, and the one time he does recount a vision that seems to have been his own, it is more unsettling than pious in its account of the origins of things: he has dreamt that he is "pregnant with Nothing like a woman with child, and in that Nothing God was born."10 This dream comes up in a

\footnotetext{
${ }^{1}$ Wayne Simsic, Praying With Meister Eckhart (Winona, Minnesota: Saint Mary’s Press, 1998), 47.

2 Timothy Radcliffe, introduction to Introducing Meister Eckhart, by Michael Demkovich (Liguori, MO: Liguori/Triumph, 2006), 11.

${ }^{3}$ Demkovich 16.

${ }^{4}$ Harvey Egan, Soundings in the Christian Mystical Tradition (Collegeville, MN: Liturgical Press, 2010 ), 156.

${ }^{5}$ Sermon 48. Edmund Colledge and Bernard McGinn, eds., Meister Eckhart: The Essential Sermons,

Commentaries, Treatises, and Defense(New York City, NY: Paulist Press, 1981), 197.

${ }^{6}$ Demkovich 23.

${ }^{7}$ Sermon 22. Colledge and McGinn 195.

${ }^{8}$ Commentaries on Genesis, ibid. 83, and Commentary on John, ibid. 132.

9 The notion of the "ground" of being, used frequently by Tillich, Rahner, and others today, may have originated with Eckhart's Middle German neologism grunt, referring to a part of the soul that is coextensive with the divine ground and, hence, has no need of being created. It is with this subversive notion that Eckhart co-opts and expands the place of the "spark of conscience" (scintilla synderesis) seated in the soul according to St. Jerome, Dionysius the Areopagite, St. Thomas Aquinas, and others. Maurice O'C. Walshe, introduction to The Complete Mystical Works of Meister Eckhart (New York City, NY: The Crossroad Publishing Company, 2009), 22-23.

${ }^{10}$ Sermon 19. Maurice O'C. Walshe, Meister Eckhart: Sermons and Treatises, Vol. 1 (London, UK: Element
} 
sermon inspired by the strange moment in Acts 9:8 when Paul, knocked off his horse, "[rises] from the ground and with open eyes [sees] nothing." Eckhart admits that the full knowledge of God, esoteric even for the angels, is a "knotty" question; how can it be, he wonders, that the light of Heaven strikes him as one that does not shine, and that he sees God only in "seeing all things as nothing?"11

This same sermon also identifies God as love; Eckhart does not despair over the apophatic vision. In this sense, however distinct his theology may be from Zen Buddhism on numerous points, ${ }^{12}$ glib comparisons to eastern spirituality nevertheless arrive at something real: calm in the face of his own nothingness, he may be better represented by the enigmatic, serene smile of Siddhartha Gautama than by the mouth of St. Theresa agape in agonized ecstasy. For him, the one who looks into the dark ground of being is one for whom "a thousand marks of red, minted gold are no more than a counterfeit penny."13

Many others have difficulty looking into the void so serenely. Admittedly, this paper is written from the point of view of a perhaps rather simple person who asks the same questions as Eckhart - Is there another there? Am I anything? What is life, and "why do [we] live"? ${ }^{14}$ - and is unsettled by his reply. Yet it is inspired more by curiosity than by defensiveness. How does Eckhart justify an essentially anti-incarnational metaphysical system within an unavoidably incarnational religion? Intriguingly, he does so through an idiosyncratic Christology that is barely elaborated upon beyond a discussion of, precisely, the Incarnation. Would a fuller consideration of the Resurrection, to which Eckhart pays virtually no attention, pose an insuperable threat to his theological framework, or does his understanding of the relationship of dependence between God and creation problematize conventional ideas about the Resurrection from the start?

\section{Eckhart's Metaphysics of Flow}

One word that evokes the vertiginous feeling of Eckhart's mysticism for many of his readers is unheimlich - the German term that denotes the uncanny, unsettling, "not like home." Indeed, an attitude of exile from the world weaves its way through much of Eckhart's work. For instance, in the Commentary on Exodus, he brusquely denigrates the human houses God builds for the midwives (Exodus 1:21) as temporal structures unworthy of those who set their sights on Heaven. ${ }^{15}$ He is uncompromising in his insistence that we must not be at home with things of the world, but rather with inward things, such as when he rebukes the "coarse-minded" materialists mentioned in my introduction:

A person who is not at home with inward things does not know what God is. It is just like a man who has wine in his cellar and, having neither drunk nor even tried it, does not know that it is good. This is the situation of people who live in ignorance: They do not know what God is yet fancy they are really living. ${ }^{16}$

\footnotetext{
Books, 1987), 157-8.

${ }^{11}$ Sermon 71. McGinn, Teacher and Preacher 320.

${ }^{12}$ Walshe, introduction to Complete Mystical Works 20. One of the great shortcomings of this paper is surely its obliviousness to the long and rich history of other religious traditions' treatment of many of the issues at hand.

${ }^{13}$ Sermon 5b. Colledge and McGinn 183.

${ }^{14}$ Sermon 6. Colledge and McGinn, 186.

${ }^{15}$ Commentary on Exodus. Bernard McGinn, ed. Meister Eckhart: Teacher and Preacher (New York City, NY: Paulist Press, 1986), 41.

${ }^{16}$ Sermon 10. Ibid. 262.
} 
Likewise, in the Commentary on John, Eckhart refers to the theological virtues as "guests and strangers" in the world yet "members of the household" in the home of God. ${ }^{17} \mathrm{He}$ accepts the Psalmist's lament that life on earth is a long and tedious exile, ${ }^{18}$ yet firmly denies that we should mitigate our sorrow through prayer because he doesn't want us to delude ourselves about reality.

In fact, he even uses the notion of exile to describe what awaits us after death. He cites Hosea 2:14: "I will lead [my beloved] into the wilderness." 19 The bosom of God to which we are to return is a "oneness" where "man is a desert and alien to himself and multiplicity." "It is a place not only where "I am what I was and what I shall remain, now and eternally," which would suggest jubilant homecoming to most of us, but where "God finds no place in man" because man has emptied himself of every image, even of God. ${ }^{21}$ Eckhart says the surest way to God is to feel "at home" with our basic homelessness. ${ }^{22}$

For the negative theologian, a dialectical language of analogy is necessary to describe God, who is incomprehensible. ${ }^{23}$ Eckhart defines God sometimes in terms of nothingness, sometimes in terms of plenitude. In the end these may amount to the same thing. In his typically recondite manner, he uses the analogy of a burning coal to explain: it is not the coal that burns the hand, but some lack in the hand of something in the coal which, if the hand had it, could not have burned the hand. "What burns in hell is nothing," says Eckhart, whereas life in God is the taking on of everything such that no omission no "nothing" is left. ${ }^{24}$ In his sermons he is fond of saying that "God's being is my life." 25 Yet when the structuring absences of the self, those "lacks" of some trait or another that make it unique and not any other self, are filled in, this being becomes:

simple ground, quiet desert, into which distinction never gazed, not the Father, nor the Son, nor the Holy Spirit. In the innermost part, where no one dwells, there is contentment for that light, and there it is more inward than it can be to itself, for this ground is a simple silence... ${ }^{26}$

One of Eckhart's most controversial ideas is that this purely simple Godhead, "into which distinction never gazed," underlies and precedes even the Trinity, for numeration of any kind

\footnotetext{
${ }^{17}$ Commentary on John Colledge and McGinn 159.

${ }^{18}$ Bernard McGinn. The Mystical Thought of Meister Eckhart (New York City, NY: The Crossroad Publishing Company, 2001), 64.

${ }_{19}$ New International Version, Grand Rapids, MI: Zondervan, 1986.

${ }^{20}$ Sermon 4. Walshe, Sermons and Treatises 42, italics mine.

${ }^{21}$ Sermon 52. Colledge and McGinn 203.

${ }^{22}$ Sermon 86. McGinn, Teacher and Preacher 341.

${ }^{23}$ Emilie Zum Brunn and Alain de Libera, Maître Eckhart: Métaphysique du verbe et théologie négative (Paris: Beauchesne, 1984).

${ }^{24}$ Sermon 5b. Colledge and McGinn 183.

${ }^{25}$ Sermon 6. Ibid. 187. He means this not just poetically, but literally. Eckhart was at odds with Aquinas's conception of creation ex nihilo. Because there is nothing that can exist outside of God, God must have created not ex nihilo, but ex deo: God, Eckhart writes, "creates all things from himself and in himself." In Frank Tobin's words, God's esse "sinks itself into the essences of things so that they might be." Frank Tobin, Meister Eckhart: Thought and Language (Philadelphia, PA: University of Pennsylvania Press, 1986), 58. Insofar as we can consider this creation out of nothing (a phrase Eckhart does use sparingly, as in Sermon 23) it is only because nothingness is a paradoxical way of describing God, insofar as God is radically different from the "something" that is created out of himself. To escape ecclesial censor and charges of pantheism in Cologne, Eckhart granted a distinction between the "absolute existence" (esse absolutum) of God and the "formally inherent existence" (esse formaliter inhaerens) of the creature, that is, "that God is the existence of all things (esse omnium) in an absolute sense, but not as formally inhering in them." (ES 33)

${ }^{26}$ Sermon 48. Colledge and McGinn 198.
} 
constitutes a fall from perfect Oneness: "Number and division always belong to imperfect things and come from imperfection." 27 The "boiling up" (bullitio) of the Trinity is secondary to the pure Godhead that grounds it and is simultaneous with the "boiling forth" (ebullitio) of creation. According to Eckhart's famed "metaphysics of flow"28 this double emanation invites us to a double return: we "are all called to return into whence [we] have flowed out," 29 first by accepting God into us in knowing ("the birth of Christ in the soul"), and then by going into God in loving (the "breaking through" of the soul into the Godhead). "The Father speaks the Son always, in unity, and pours out in him all created things," Eckhart writes. "...All their life and their being is a calling and a hastening back to him from whom they have issued." 31

The implications of this metaphysics of flow, with its clear resemblance to the neoplatonic systems of earlier days, challenge some key precepts of classical Christian mysticism, which "always retains a certain, though subtle, degree of differentiation" between the creature and God in their divine union. ${ }^{32}$ Eckhart, in contrast, is concerned with that which is undifferentiated: first of all, the Godhead itself, totally pure in the deep waters that boil and bubble only eventually into the Trinity, but also the human self, which in a "pure unknowing and forgetting of self and all creatures" must detach itself even from the accidents of its human personality. ${ }^{33}$ In a popular manual on spirituality, Michael Demkovich insists that Eckhart's mysticism is orthodox, and that it is "incarnational" rather than "escapist." "H4 However, this is far from clear given the extent of the detachment Eckhart enjoins: "Man must go out of every image and out of himself and out of everything, he must go far off indeed, and become quite unlike all this, truly," if he wishes to approach the Father to whom "every kind of medium is alien." 35

St. Bernard of Clairvaux, representative of a more mainline strand of Christian mysticism, was clear that the love between God and soul subsists in a mutual presencing that does not entail dissolution: the lovers are unusnon unum, united but not one. ${ }^{36}$ Eckhart's main metaphysical claim is precisely the opposite: God is unity itself, so in the breaking through to God, what results must be unum non unus. ${ }^{37}$ Words and concepts, of course, do no justice to the experience, and for most Christians speculation about union with God is idle anyway-unless one subordinates it, along with all one's intelligence and all one's ignorance, to faith in the power and promise of Christ. Christ is seen as mysteriously guaranteeing the integrity of the body even as he pledges to lead us to Heaven. What does Eckhart, the metaphysician, have to say about the Incarnate one?

\footnotetext{
${ }^{27}$ Commentaries on Genesis. Colledge and McGinn 99

28 A term coined by Alain de Livera in reference to Eckhart's teacher Albert the Great, but popularized in Eckhart studies by Bernard McGinn. The Mystical Thought of Meister Eckhart 217.

${ }^{29}$ Sermon 53. Colledge and McGinn 205.

30 Sermon 6. Ibid. 188.

${ }^{31}$ Sermon 53. Ibid. 205.

${ }^{32}$ C.F. Kelley, Meister Eckhart on Divine Knowledge(New Haven, CT: Yale University Press, 1977$), 2$.

${ }^{33}$ McGinn, The Mystical Thought of Meister Eckhart 63.

${ }^{34}$ Demkovich 21.

35 The Book of Benedictus: On the Nobleman. Colledge and McGinn 243-4. Much could be said about Eckhart's method of detachment, a major motif in his work. Famously and surprisingly, he prefers the example of the hardworking Martha to the starry-eyed Mary in Luke 10; in his view, Mary is naïve, for she is seeking God in a contemplative "way" and, in finding a "way," will miss out on true God. Martha, on the other hand, realizes that to work as though nothing else mattered - no higher self-realization - is the true paragon of detachment, what Eckhart calls "living without a Why." Sermon 86. McGinn, Teacher and Preacher 338-345.

${ }^{36}$ See, for instance, On Loving God 10:28 and Sermons on the Song of Songs 71:7-10.

${ }^{37}$ Walshe, introduction to Complete Mystical Works 18.
} 


\section{Eckhart's Christology}

The role of Jesus Christ is vexed even in a more conventional mysticism than Eckhart's. According to the via negativa and its preference for imageless transcendence over immanence, it could seem that "the contemplative must not pay attention to thoughts about Jesus," whose own example of deep prayer is of use primarily "during contemplative distractions or trials," and whose humanity must get "left behind" once more advanced prayer sets in.. The author of the Cloud of Unknowing, for instance, cites Jesus' saying that "it is for your good that I am going away" (Jn 16:7), making clear the need to cast our eyes upward, towards the apophatic Godhead. ${ }^{38}$ Still, many mystics' experiences of sharing Jesus' passion or of quasi-sexual mystical union with him provide incarnational counterpoints to airy spiritual tendencies.

For his part, Eckhart mentions Jesus very rarely. References to the Passion are almost completely absent, and when they do appear, it is only to reassure the pious that they need not be scrupulous in imitating Christ's every agony. ${ }^{39}$ Though Eckhart is not naive about the need to suffer in this life, ${ }^{40}$ this is not a major theme; Christ's death has a more general and theological meaning for him, as the prime example of self-emptying kenosis in deference to God's will. Our own efforts at imitating Christ's detachment seem to have more to do with our redemption than Jesus' death on the Cross. Christ did not die for us so much as become incarnate for us, and thisis how we are to become intimate children of God in our own right.

Eckhart's fifth sermon is a meditation on the Christian truth that "God has sent His OnlyBegotten Son into the world." According to Eckhart's Incarnational Christology, we "must not understand by this the external world in which the Son ate and drank with us, but understand it to apply to the inner world [where] God's ground is my ground, and my ground is God's ground." ${ }^{1}$ This ground - identical with God's ground, and therefore uncreated - is described elsewhere as a "spark" and as a "real castle," as in the following arresting geography of the created soul:

The true image of the soul emerges when it has been formed and fashioned out of nothing that is not God himself. The soul has two eyes...The inward eye of the soul is the one that sees into being and takes its being from God without anything else mediating. This is its proper function. The outward eye of the soul is the one that is turned toward all creatures, taking note of them by means of images in the manner of a [spiritual] faculty. The person who is turned in on himself... is free of all created things and is enclosed in himself as in a veritable fortress of truth. I once said that our Lord came to his disciples behind locked doors on the day of Easter. It is the same with the person who has been freed of all otherness and createdness. God does not come to this person. He is there already as being. ${ }^{42}$

This is more than a tame injunction to store up treasures in heaven rather than on earth. Eckhart, typically apophatic, identifies receptivity to God as freedom from otherness and createdness, which is to say, freedom from self. He follows the precepts of negative theology in insisting that even God must shed all images and attributes in order to dwell here. ${ }^{43}$ What is more radical than this is the notion that the Word, apart from God and the individual believer, also takes

\footnotetext{
${ }^{38}$ Harvey D. Egan, Christian Mysticism: The Future of a Tradition (New York City, NY: Pueblo Publishing Company, 1984), 110-111.

${ }^{39}$ Counsels on Discernment. Colledge and McGinn 267-8.

${ }^{40}$ The Book of Benedictus: The Book of Divine Consolation. Ibid. 231.

${ }^{41}$ Sermon 5b. Ibid. 183.

${ }^{42}$ Sermon 10. McGinn, Teacher and Preacher 263.

${ }^{43}$ Walshe, introduction to Complete Mystical Works 20.
} 
root in this undifferentiated inner ground such that "the man" God becomes - Jesus Christ - is only an external appurtenance (easily dismissed if not purposely ignored) of the more significant act of God's taking on human nature in general. ${ }^{44}$ More radical still is the idea that in our imitatio Christi, we are then enjoined to love all people equally, but only their nature and not what makes them unique as individuals. ${ }^{45}$ Most radical of all is that in this imitation, God "gives me birth, me, his Son and the same Son...not only to me, his Son, but he gives birth to me as himself," i.e., as the Father. ${ }^{46}$ One of the main points of contention at Eckhart's heresy trials was this notion that we are "Sons of God" in the same way that Jesus was, ${ }^{47}$ and that we ourselves participate in the divine Trinity. ${ }^{48}$ For those of us who are not Inquisitors but wonder what Eckhart's Christ offers us, it is a double-edged sword: complete and total oneness with him and with God, but also the loss of our individuality.

Eckhart preached extensively, and it is only natural that he sometimes forayed into the traditional pietistic language of his time. In Sermon 56, for instance, we read: "All things must be dipped in the blood of Christ and brought back into the Father by the mediation of the Son himself; just as the Father does everything through the Son, so must the flowing back match the flowing out."49 Even here, though, it is the Incarnation and not the Passion that is the key link in the metaphysics of flow, "tasting the nature" of both humanity and divinity, ${ }^{50}$ but ultimately exerting an attractive force towards God rather than remaining in tension in the middle. In saying that the soul's "breaking through is nobler than his flowing out," 51 and thus giving eschatology its ultimate direction, Eckhart isn't saying anything other than what theologians had said for centuries and what they have said for centuries since: God became one like us so that we might become like God. Yet with or without his docetic mitigation of the importance of Christ's humanity, it is clear that death to the world is not just an ascetic tactic here; it severely problematizes the dogma of the resurrection of the body. One of Christianity's central claims is that in Christ humanity and divinity are able to co-exist harmoniously. Eckhart seems unable to say this. In his understanding, Christ calls us away from our humanity forever. Can we be at home in Him?

\section{Eckhart on Creation and Eschatology}

Consistent with Eckhart's high Christological style and lack of significant interest in Christ's humanity, he understands the plenitudo temporis of Galatians 4:4 not as a single historical moment when God finally decided to send his Son into the world, but as the sense in which every moment in time is fully present to God in the eternal now: "everything God made six thousand

\footnotetext{
${ }^{44}$ Gabriel Théry, “Contribution à l'histoire du procès d'Eckhart," La vie spirituelle. Supplement 9 (1924-1926), 202.

45 Théry 233-4. Eckhart feels strongly that the structuring absences germane to creation, which cause distinction and differentiation among souls, are traces of $\sin$ (where sin is conventionally understood as an absence of the good, of God, of wholeness); and that to love individuals rather than their Godly nature is to prefer something containing sin to something not containing sin. He feels $s o$ strongly about this, in fact, that he reserves one of his exceedingly rare mentions of "the Enemy" for this formulation: "These [the imperfections in people's nature] are not God's seed; he did not plant them; they are not his work. They are...the Enemy's." (Commentary on John, ES 161) Eckhart nowhere really elaborates on the place of this "Enemy" in his cosmos.

${ }^{46}$ Sermon 6. Colledge and McGinn 187-8: Eckhart compares this to the Transubstantiation that occurs during the consecration of the Eucharist, as though he were not being provocative enough already.

${ }^{47}$ McGinn, The Mystical Thought of Meister Eckhart 125.

${ }^{48}$ Walshe, introduction to Complete Mystical Works 19.

${ }^{49}$ McGinn, The Mystical Thought of Meister Eckhart 126.

${ }^{50}$ Ibid. 119.

${ }^{51}$ Sermon 52. Colledge and McGinn 203.
} 
years ago and more when he made this world, God is creating now all at once." ${ }^{, 52}$ This means that the beginning of the world, the principio of Genesis and John, is not at all privileged. For Eckhart, "time and all things temporal are seen from the standpoint of eternity, from which the question of whether the world had a beginning or not is of no consequence." 53 Rather, everymoment emanates, at once and equally, from the "hidden darkness of the eternal divinity." 54

It should not surprise us that a theologian averse to the accidents of human personality should also be averse to the accidents of history that attend any particular moment in time. Yet things get complicated when Eckhart, defending himself from charges of heterodoxy in Avignon, backs off from anything that might suggest that he believes in the eternity of the world. He elaborates on the implications of his sense of God's creation: "It does not follow that because God's action [actio] is eternal, [the world] is eternal, because God produces the world from the start and out of time and in the now of time in such a way that the world and its creation is a reception [passio] in time, and the now of time and creation as reception are not in God but in the creature." 55

This is a little unusual for Eckhart, who customarily refers to the difference between eternal God and transient world as the difference between esse virtualeand esse formale, where the former is the eternal holding of an idea of creation in the mind of God (basically, the Logos before its Incarnation) and the latter is the inferior sort of existence that results when the idea "flows forth" into actual matter. In this as in so much else, Eckhart is typically neoplatonic: the created object pales in comparison to its ideal form or image.

In the Avignon defense, however, Eckhart dips into Thomistic territory, where the distinction is between actio and passio -- terms with their own intellectual history well known to Eckhart's Inquisitors. Elsewhere, Eckhart may have disparaged what he understood as the Thomistic idea that God, as the efficient cause of creation, creates something ex nihilo with an independent existence outside of God. ${ }^{56}$ Here, however, he joins himself to a Thomistic language and metaphysics of creation. McGinn explains," "in the Aristotelian language of actio/passio drawn from the analysis of motion these two moments are simultaneous aspects of the same production, movement, or change. This is why," he continues, "Thomas Aquinas had denied that creation should be conceived of in terms of a motion, or change, but rather as the beginning of a relation of dependence." 57 Thomas seems to have been torn between the obligation to affirm on faith the revealed teaching of the Church that the world had a beginning ${ }^{5859}$ and his philosophical sympathy for Aristotle's belief in the eternality of creation and created life. ${ }^{60} \mathrm{He}$ seems to have reconciled this tension by justifying philosophically a hypothetical argument for the plausibility of the eternality of the world. His intellectual triumph was to nuance the meaning of the words "creation" and "eternal": he made it clear that creation referred not to a beginning in time but to a perpetual dependence of the world in its continual process of becoming on God, and then proposed

\footnotetext{
52 McGinn, The Mystical Thought of Meister Eckhart 236.

${ }^{53}$ Walshe, introduction to Complete Mystical Works 19 and 22.

${ }^{54}$ Sermon 22. Colledge and McGinn 196.

55 Votum theologicum in Théry 186-7.

56 Théry 207. Cf also footnote 24.

${ }^{57}$ McGinn, The Mystical Thought of Meister Eckhart 105.

58 ST I, 46, 2.

59 STI, 46, 2.

${ }^{60}$ M.F.J.M. Hoenen, "The Literary Reception of Thomas Aquinas' View on the Provability of the Eternity of the World in de la Mare's Correctorium(1278-9) and the Correctoria Corruptorii (1279-ca 1286)," in The Eternity of the World in the Thought of Thomas Aquinas and his Contemporaries, ed. J.B.M. Wissink (New York City, NY: E.J. Brill, 1990), 48.
} 
that the world could be eternal, not in the sense of being simultaneously whole, as only the pure act that is God can be, but in the sense of having an infinite duration in time. ${ }^{61}$

For the purposes of our discussion, whether creation has or does not have an infinite duration in time is not of central importance. The point is that thanks to Aquinas's redefinition of these terms, we can see that whether one commits to a finite or an infinite duration of time, creation itself, as it unfolds in time, must be understood to be locked in a relation of eternal dependence on God. This relation cannot simply be undone, and even if one abandons Thomistic metaphysics, it is hard to imagine a universe in which it could be undone. The eternality of God seems automatically to bestow a dignified persistence in memory even unto creation. If forced to describe the miracle of creation in temporal terms, we might say that what is, now, always will have been - at least in the mind of God.

For Aquinas, this does not pose a problem. The mind of God, after all, is precisely what we hope to attain in the beatific vision, where this "vision of God" is to be understood, for all intents and purposes, as both a subjective and an objective genitive: "What is there that they do not see," Aquinas quotes Gregory the Great, "who see Him who sees all things?"62 Union with God---which, for Aquinas as for the conventional Christian mystics, is not the same as identity with God-_- does not demand forgetfulness of who we are and have been. Nothing is lost. In fact, the absolute perfection of knowledge and charity contained in this union is overwhelmingly greater than the happiness known even to the prelapsarian couple, who in Aquinas's framework did not yet enjoy the beatific vision. For this reason, we might question Chenu's conventional description of the Summa, as itself bearing a structure of exitus-reditus. the relationship with God to which we "return" at the end of our supernatural elevation by grace is not the same as that from which we came. ${ }^{63}$

For Eckhart, however, creation does not have the upbuilding function of a divine pedagogy, which offers us growth in knowledge and virtue until we reach a state of utter beatitude. All that matters for Eckhart is the reditus, an about-face turn back towards a true paradise that has been lost. His treatment of this theme in the Commentary on Genesis is fascinating. He dramatically attenuates the notion of personal sin in Eden and reads the whole story of the first couple as an allegory of the fall from "naked" purity to a world of misguided concern for "particular" things. The incarnational Christology he traces in this commentary looks more Franciscan than Dominican, with its sense that the incarnation was eternally intended by God and was not an emergency response to our decision for sinfulness; yet his view of creation, if ultimately more impassive than anguished, is not only less cheerful than the Franciscan view, but less sanguine than his Dominican confrere Aquinas's. The obstinate irrevocability of creation I have proposed above might perhaps appear to Eckhart as it did centuries later to Nietzsche: as the heaviest of burdens (das schwerste Gewicht), next to which even the entirely unheimlich exile from one's self implied by the return to the desert of God seems desirable.

\section{The Resurrection of the Body}

\footnotetext{
${ }^{61}$ Variabilitas de sui ratione excludit aeternitatem, writes Aquinas, non autem infinitam durationem: "Changeableness, by its nature, excludes eternity, yet not infinite duration" (De pot., III, 14, ad. 3). $\mathrm{f}$

${ }^{62}$ De Veritate II, 2, reply.

${ }^{63}$ Rudi Te Velde gives other reasons to dissent from Chenu's well established view. Aquinas on God: The "Divine Science" of the Summa Theologiae (Burlington, VT: Ashgate, 2006), 10-18, et passim.
} 
Given that time belongs to the created order, it would be inappropriate to understand Eckhart's reditus in the way that many people understand Heaven: as occurring "after" this life. Timelessness cannot come "after" anything in time any more than creation can be construed as the simple beginning of the flow of time after a certain period of timelessness. The point of the mysterious disanalogy between actio and passio, wherein time-bound creation is nonetheless left suspended in a relation of dependence with the eternal one, is that neither the beatific vision of Aquinas nor the apophatic vision involved in the Eckhartian "breaking through of the soul to God" can be construed simplistically as a final understanding or final oblivion. Of course, meditations on our last end can never aim at comprehension of its mystery. This is clear.

It is important to emphasize once more the glaring lacuna in Eckhart's Christology: Jesus' resurrection, which the sermons hardly ever mention. Rather than a metaphysics of flow and reditus, the Gospels imagine that somehow, after the incarnation (of Christ, and our own), God's love flows forth even further into a new creation symbolized by the Resurrection. Still, it naturally remains a mystery how to imagine the resurrection of the dead given the eschatological problem of time. Does the Resurrection compel us to believe that our image of eternity should be more along the lines of an infinite duration of time, albeit in a new earth, than of a pure and simultaneous wholeness outside of time? We might look at Scripture.

The Pauline Resurrection Body, which does not supplant the earthly body but grows from it, as a plant bursts forth from within a seed, and the post-Resurrection Jesus (who is difficult to recognize in the Gospels, but who still eats and bleeds, and is clearly no merely ethereal ghost) provide potent images that may not be incompatible with the Eckhartian "Eternal Now." They suggest that the Kingdom of Heaven - the breaking through of the soul to God - is precisely as Jesus described it to his disciples: as coming not soon or after (false categories for the timeless), but within us, in our midst.

Whether they believe that all things are intelligible or that all things are as naught, Aquinas and Eckhart both interpret what it means, in Scripture, to "see" God philosophically and very metaphorically, indeed. We should mention that a different and more literal vision of the life after this life is hypothetically possible, in which "the opposition between corporeal and spiritual senses is unthinkable and superfluous," and images of cities, feasts, and the other materials of our embodied existence serve as more than just symbols. ${ }^{64}$ This vision is represented by von Balthasar's depiction of John of the Apocalypse, who is not "transported from the earth to God to see the unspeakable," as Paul is in the revelation on the road to Damascus that so moved Eckhart, but who, in heaven, "again finds the reality of earth, only from the perspective of heaven; in heaven he finds the reality of faith on earth, not only as a reality that is seen but as a reality that also sees." This is a poetic, not a philosophical vision, and von Balthasar seems to defend its plausibility by saying that if it is possible it is "simply assuming that in love everything is possible." ${ }^{65}$

It may be unfair to assume that love is not the hermeneutic key to Eckhart's mysticism -- I have, after all, already cited his twenty-second sermon, to the effect that all sorrow and all joy come from love. When Benedict XVI tries to evoke the true meaning of eternal life in a passage from his second encyclical, we can hear echoes of our own discussion of time, and wonder whether Benedict's Augustinian weariness over the toil and travail of life on earth and Eckhart's more sober contemplation of the perfection of God are congruent and coterminous, and may both have their solution in God's love:

\footnotetext{
${ }^{64}$ Hans Urs von Balthasar, The Glory of the Lord: A Theological Aesthetics. Volume I: Seeing the Form, trans. Erasmo Leiva-Merikakis (San Francisco, CA: Ignatius Press, 1998), 358.

${ }^{65}$ Ibid. 359.
} 
To imagine ourselves outside the temporality that imprisons us and in some way to sense that eternity is not an unending succession of days in the calendar, but something more like the supreme moment of satisfaction, in which totality embraces us and we embrace totality - this would be like plunging into the ocean of infinite love, a moment in which time, the before and after, no longer exists. We can only attempt to grasp the idea that such a moment is life in the full sense, a plunging ever anew into the vastness of being, in which we are simply overwhelmed with joy... ${ }^{67}$

Is this just a gentler and perhaps more appealing way to privilege, over von Balthasar's differentiated and incarnate vision of our final destiny, the atemporal union with totality Eckhart was gesturing towards? Yet immediately following this passage, Benedict explicitly interprets its rather Nirvana-like bliss through Jesus' Scriptural promise to the disciples that he will see them again. Their hearts will rejoice, and no one will take their joy from them (Jn 16:22). Personal recognition of, and reunion with, those we love, in all their particularity, seems a perpetual prerequisite for so many of us if we are to aspire towards whatever is meant by the symbol "heaven."

Whichever way we look at it, the unheimlich adheres both to our incomplete existence here on earth and to the notion of an overwhelming plenitude on high that threatens to obliterate who we are. Perhaps the dogma of the resurrection can help us to escape the deep melancholy of the death of self implied in Eckhart's detachment while also accounting for his manifest joy at the thought of returning to God. The dogma cannot be definitively understood. In saying that God is personal, we mean not to anthropomorphize but to insist that in the categories of our inadequate understanding, God is nonetheless more personal than thingly. Likewise, we cannot know what the resurrection will look like, but we trust that in God's goodness we are to be more like someone than like no one; we know that "our lives will not end in emptiness." ${ }^{168}$

There is a literary analogue to this theological question. When Adam asks St. Michael to describe Heaven in Milton's Paradise Lost, the archangel agrees to give him at least a rough idea, through symbolic language... yet not without asking impishly and provocatively, "Though what if earth / Be but the shadow of heav'n, and things therein / Each to other like, more than on earth is thought?" Then Heaven and Earth alike would feel a little more heimlich than not.

\footnotetext{
${ }^{67}$ Benedict XVI. Encyclical letter. Spe Salvi 12, November 30, 2007. http://www.vatican.va/holy_father/benedict_xvi/encyclicals/documents/hf_ben-xvi_enc_20071130_spesalvi_en.html.

${ }^{68}$ Ibid. 2.
} 